\title{
Jakobson: \\ Translation as imputed similarity
}

\author{
Bruno Osimo \\ Higher Institute for Translators and Interpreters (ISIT) \\ Translation Dept. of the Scuole Civiche di Milano Foundation \\ via Alex Visconti 18, 20151 Milano, Italy \\ e-mail: osimo@trad.it
}

\begin{abstract}
Jakobson, in his essays, has tried to insert Peirce's typology of signs (icon, index, symbol) in his own binary logic, in which every feature of a text may be considered or dismissed either with a 0 or with a 1 (absent, present). In so doing, he used the features "similarity versus contiguity" and "imputed versus factual", and discovered that the notion of "imputed similarity" was not covered by Peirce's triad. Hence the search for it. In this article, whose ideological basis and quotations are mostly from Jakobson's essays, the author tries to show that the notion of "translation" may be the missing link. Starting from Peirce's main triad, and its initial incomprehension among Western scholars influenced by Saussure, the interpretant is then viewed as the subjective, affective component of sign and its interpretation. Syntax, considered in Peircean and Jakobsonian terms, is iconic. The evolution of meaning, characterizing all communication, is possible thanks to construction and thanks to metaphoric and metonymic connections. In the last part of the article, cultural implications of communication - and translation - are considered.
\end{abstract}

\section{Peirce's triad}

Western-European linguistics, in the 20th century, starts from the arbitrary relationship between sign and object presumed by Saussure. This was an easy way to get rid of a difficult problem, namely, the 'black box' part of semiosis. When the word is a pure symbol (i.e. it has no features of the icon, or of the index), how does it link to the meanings that are subjectively or culture-specifically attributed to it? 


\section{Bruno Osimo}

How does a culture (i.e. a person, or a group) 'decide' that such a sound pattern is connected to some specific phenomenon? Maintaining that such a link is arbitrary is a (too easy!) solution, even if more than one previous scholar had warned against such a simplification:

The essential precondition of the envisaged inquiry had been posited by an earlier French thinker, Joseph de Maistre: "Ne parlons donc jamais de hasard ni de signes arbitraires". (Jakobson 1971b: 722)

So, if we want to reconstruct what happened in European linguistics in 20th century having in mind the broader picture, and why today we have to work hard to collect missing pieces partly from the East and partly from the West, we have to consider that we were culturally dominated by what Saussure's students had left us, in the form of two dogmas:

When postulating two primordial linguistic characters - the arbitrariness of the sign and the linearity of the signans - Saussure attributed to both of them an equally fundamental importance. (Jakobson 1971g [1965]: 357)

Charles Sanders Peirce had lived and written thousands of pages on the subject, but nobody in Europe had read his works, that were mostly unpublished in the U.S. as well. Linguistics, in Western Europe, was still considered a discipline far from communication theory (which did not exist) or semiotics (not yet 'discovered'). Nobody here - in contrast to Filipp Fedorovich Fortunatov in Russia, for example - attempted to consider linguistics as an exact science maybe based on a mathematical model of communication -, which could have explained the workings of signification in general, and signification of verbal signs as a particular case.

We deal with language as a universal invariant with respect to varied local languages which are variable in time and space. In the same order of things, semiotics is called upon to study the diverse systems of signs and to bring out the problems which result from a methodical comparison of these varied systems, that is to say, the general problem of SIGN: sign as a generic notion with respect to the particular classes of signs. (Jakobson 1985d [1975]: 199)

Hence the very hard effort of Jakobson, who tried to popularize Peirce's thought, which he had got acquaintance with thanks to a very 
adventurous life characterized by many geographical moves, the last of which was to the United States. And thanks to a very peculiar scientific curiosity and thirst for knowledge. In a century now known to history for the demolition of communication barriers, it seems almost unthinkable that, to be able to have a syncretic view of the thought in one's own scientific field, one should have to 'travel through science', explore most libraries and lists of references and discover here and there what was written and was not yet spread to the rest of the world. But looking at Jakobson's biography, it really seems his case. In his approach to scientific writing, Jakobson is very different from such scholars who aspire to be understandable only by their colleagues in the strict sense of the word - he explains and translates terminologies:

Peirce [...] makes a clear-cut distinction between the "material qualities", the signans of any sign, and its "immediate interpretant", that is, the signatum. Signs (or representamina in Peirce's nomenclature) offer three basic varieties of semiosis, three distinct "representative qualities" based on different relationships between the signans and signatum. This difference enables him to discern three cardinal types of signs. (Jakobson 1971g [1965]: 346)

Maybe to be more understandable in Europe, maybe because he did not like neither Saussure's (signifiant, signifié) nor Peirce's terminology, maybe because he wanted to show the tie with Medieval thought in philosophy of language, Jakobson uses the Latin words signans (Saussure's 'signifiant' and Peirce's 'sign') and signatum (Saussure's 'signifié' and Peirce's 'object'). Since both Latin terms are participles, they could be - partially — intended as present participle of the verb "sign" ("signing") and past participle of the verb "sign" ("signed"), but in English the interference of the historically secondary meaning of "subscribe" would perhaps be too strong. Signs may be objects, i.e. tangible things:

This use of things as signs, which the Czech inquirer into this peculiar form of communication, I. Osolsobě, has labeled "ostension", may be illustrated by the exhibition and compositional arrangement of synecdochic samples of shop goods in show windows or by the metaphoric choice of floral tributes. (Jakobson 1971i [1968]: 702)

In the following excerpt from Jakobson's article from 1965, the three types of signs in Peirce's system are explained. Please note that, in 


\section{Bruno Osimo}

doing so, Jakobson has in the foreground the notion of "distinctive trait": every type of sign is described first of all according to the dichotomies factual/imputed and similarity/contiguity. The latter is fundamental in Jakobson's thought, since it is at the center of his studies on aphasia and on metaphor and metonymy. Quotations within the quotation are - of course - from Peirce ${ }^{1}$ :

1) The icon acts chiefly by a factual similarity between its signans and signatum [...]. 2) The index acts chiefly by a factual, existential contiguity between its signans and signatum, and "psychologically, the action of indices depends upon association by contiguity" [CP 2.306] [...]; Robinson Crusoe found an index; its signans was a footprint in the sand, and the inferred signatum, the presence of some human creature on his island [...]. 3) The symbol acts chiefly by imputed, learned contiguity between signans and signatum. This connection "consists in its being a rule" [CP 2.292] and does not depend on the presence or absence of any similarity or physical contiguity. (Jakobson 1971g [1965]: 347)

In another, subsequent, article, Jakobson makes clear his way of systematizing Peirce's signs according to the two dichotomies. It looks as if Jakobson's cooperation with Peirce - had they lived at the same time and in the same place - would have produced great results, since Jakobson has a closer attention to systematization and clarity of expression, to the translation of the metalanguage, to didactics.

The division of signs [...] is actually based on two substantial dichotomies. One of them is the difference between contiguity and similarity. The indexical relation between signans and signatum consists in their factual, existential contiguity. The forefinger pointing at a certain object is a typical index. The iconic relation between the signans and the signatum is, in Peirce's terms, "a mere community in some quality" [CP 1.558], a relative likeness sensed as such by the interpreter, e.g. a picture recognized as a landscape by the spectator. We preserve the name symbol used by Peirce for the third class of signs [...] no factual proximity is required between the noun car and the vehicle so named $[. .$.$] the symbol "may be termed an imputed quality" [CP$ 1.558], according to Peirce's felicitous expression of 1867. (Jakobson 1971i [1968]: 699-700)

A translation process, leading from sign to object, concerns all types of signs. In semiotics, verbal language is not the center, the Ptolemaic

1 References to Peirce's works, added in square brackets in this and following quotes, are mine - B.O. 
Earth around which all other sign systems rotate, as in semiology except for metalanguage whose object language is verbal language. However, the workings of words (i.e. verbal symbols) are one of the main sources of Peirce's reflections on signs:

The predominant task of symbols in our verbal (and not only verbal) creativity could be considered the mainspring of Peirce's doctrine, but I hate to use the label "doctrine", for the thinker himself categorically declared that for him science was not doctrine, but inquiry. (Jakobson 1985f [1977]: 253)

The reluctance to use the word "doctrine" is part of the attempt to build a view of linguistics as an exact science. In any case, the distinction between imputed and factual relationship, and between similarity and contiguity, must not be taken as an absolute divide: in most cases, if not in all cases, signs have some traits of more than one of these features. As in every other field, there is no purity; it is rather a question of nuances, of more or less insisted qualities.

It is not the presence or absence of similarity or contiguity between the signans and signatum, not the purely factual or purely imputed, habitual connection between the two constituents which underlies the division of signs into icons, indices and symbols, but merely the predominance of one of these factors over the others. [...] "It would be difficult, if not impossible, to instance an absolutely pure index, or to find any sign absolutely devoid of the indexical quality" [CP 2.306]. Such a typical index as a pointing finger carries dissimilar connotations in different cultures; for instance, in certain South African tribes the object pointed at is thus damned. (Jakobson 1971g [1965]: 349)

Connotation, in this passage, looks like an affective component of signs, culturally subjective in an individual or group sense. Were the signs arbitrary, there could not be any affective component. Affects play a role in signification from the moment when the sign triggers the interpretant within the interpreter. And, since every individual has a different life with different experiences, the apperception of everyone is different; hence, emotions linked to signs (connotation) are idiosyncratic.

Peirce's concern with the different ranks of coassistance of the three functions in all three types of signs, and in particular his scrupulous attention to the indexical and iconic components of verbal symbols, is intimately linked with his thesis that "the most perfect of signs" are those in which the iconic, 
indexical, and symbolic characters "are blended as equally as possible" [CP 4.448]. Conversely, Saussure's insistence on the conventionality of language is bound to his assertion that "The entirely arbitrary signs are the most appropriate to fulfill the optimum semiotic process." (Jakobson 1971g [1965]: 349)

In Saussure's opinion, it would seem, optimization of semiosis means abstraction from human reality (unaffective symbolism) and from emotions. His hypothesis of semiosis is devoid of any affects, which actually are the glue of acquisition of knowledge. The strength of memory is directly proportional to the intensity of affect linked to memorization. In Peirce's opinion, by contrast with Saussure, perfect semiosis is a mixture of all the types of signs:

Peirce does not at all shut signs up in one of these three classes. These divisions are merely three poles, all of which can coexist within the same sign. The symbol, as he emphasized, may have an icon and/or an index incorporated into it. (Jakobson 1985f [1977]: 253)

Thus the "purity" of signs is impossible at the practical level. Moreover, according to different parameters, there are different subspecies of signs. For example, there are different types of icons:

The correspondence in order between the signans and signatum finds its right place among the "fundamental varieties of possible semiosis" [CP 5.488] which were outlined by Peirce. He singled out two distinct subclasses of icons - images and diagrams. In images the signans represents the "simple qualities" [2.277] of the signatum, whereas for diagrams the likeness between the signans and signatum exists "only in respect to the relations of their parts" [CP 2.282]. (Jakobson 1971g [1965]: 350)

Saussurean dichotomy and Peircean trichotomy are irreconcilable: they are two different views that lead from the same examples to different conclusions. The combination of the two views, if not "carefully handled", generates confusion because they refer to the same entities with different terms and to different entities with the same terms. A practical expression of this kind of confusion is the example used by Saussure to illustrate something that in Peircean terms would be the object, for Jakobson an iconic symbol, and for Saussure something completely different: 
As to the icon, it is able to present [...] a sample of a given species of trees in a certain part of the year - a maple tree during the warm season, as in Saussure's illustration [...]. If the meaning of such an icon is generic, its generic sense is achieved through a synecdochic device of a pars pro toto; the icon becomes an 'iconic symbol'. (Jakobson 1971e [1959]: 268)

If one stressed too much the individual, idiosyncratic level of semiosis, of meaning extraction or production, there could be doubts about the possibility of mutual understanding. But the social animals that men are express themselves through the ability to conjecture what could be the sense of a given contextualized sign for someone else, for the projection that everyone of us makes of the expected, supposed, general other:

When considering even the apparently simplest processes going on in language, it is necessary to keep in mind the force of unconscious generalization by the action of which a people subsumes all the phenomena of its mental life under certain general categories. (Baudouin de Courtenay, quoted in Jakobson 1985g [1978]: 149)

Such a generalizing projection is possible because we store in our mind a lot of information concerning the world. In this storage, we also keep what we did not understand and what we forgot we had understood. This is of great help when we try to guess about the rest of the world, or about the future:

"habit, i.e. unconscious memory" and on the other hand, "unconscious oblivion and incomprehension (forgetting of what was not consciously known and incomprehension of what could not be understood consciously); such forgetting and incomprehension constituting not something inconsequential and negative". (Baudouin de Courtenay, quoted in Jakobson 1985g [1978]: 150)

Of course, many tasks stand ahead in the systematization of signs and their typology. One is that, applying the two aforementioned dichotomies, a fourth kind of sign should emerge, as Jakobson promptly warns: imputed similarity.

However, the interplay of the two dichotomies — contiguity/similarity and factual/imputed — admits a fourth variety, namely, imputed similarity. Precisely this combination becomes apparent in musical semiosis. The introversive semiosis, a message which signifies itself, is indissolubly linked with the esthetic function of sign systems and dominates not only music but also 
glossolalic poetry and nonrepresentational painting and sculpture. (Jakobson 1971i [1968]: 704-705)

To these examples of Jakobson's, one might add some particular actualizations of onomatopoeia, if one thinks of the verbal representation of the sounds of animals. Dog barking, for example, is different in every language: if in English dogs woof, while in Italian bau bau, in French ouah ouah, in Russian gav gav, and in Chinese wang wang, all these must be imputed similarities. But how could we name the fourth kind of sign? My proposal would be "homopoiesis", since it is a similarity (hence the root "homo-") that is creatively attributed (imputed). It sounds like an oxymoron at first, but, if you think of the mentioned examples, it is something that we do.

Jakobson, however, has another idea of imputed similarity: the device or, according to Russian Formalists, priem, that is every artifice or method or mechanism or figure used by writers (speakers) to modify the 'normal', unaffective way to express something:

The "artifice" is to be added to the triad of semiotic modes established by Peirce. This triad is based on two binary oppositions: contiguous/similar and factual/imputed. The contiguity of the two components of the sign is factual in the index but imputed in the symbol. Now, the factual similarity which typifies icon finds its logical foreseeable correlative in the imputed similarity which specifies the artifice, and it is precisely for this reason that the latter fits into the whole which is now forever a four-part entity of semiotic modes. (Jakobson 1985d [1975]: 215; my emphasis - B. O.)

Following his hint, one might propose that the fourth kind of link, or imputed similarity, is free association: a similarity that initially holds true only for the person who proposes it, that is imputed by him. Eventually, such a similarity is shared by listeners/readers, who come to see the object from a fresh point of view. This discovery of Jakobson's has a great potential, a potential that, however, was not yet fully displayed.

Another problem linked to sign typology that Jakobson leaves us to solve is the polymorphous nature of semiosis:

the linearity of the signans [...] has been shaken by the dissociation of phonemes into distinctive features. With the removal of these fundamentals, their corollaries in turn demand revision. Thus Peirce's graphic and palpable idea that "a symbol may have an icon [and/] or [...] an index incorporated into 
it" [CP 4.447] opens new, urgent tasks and far-reaching vistas to the science of language. (Jakobson 1971g [1965]: 357)

Since, with the permission of Saussure, we may consider the nonlinear nature of the sign, there is room to imagine that any sign, according to what parts of it are put into light - iconic, symbolic, indexical, affective - may bear different senses.

\section{Syntax, paradigm}

Sentence construction is another field that Jakobson approaches with a scientific attitude. Starting from some of Peirce's observations on the diagrammatic nature of verbal language, he tries to continue on his path:

"algebra is but a sort of diagram", and "language is but a kind of algebra" [CP 3.419]. Peirce vividly conceived that "the arrangement of the words in the sentence, for instance, must serve as icons, in order that the sentence may be understood" [CP 4.544]. (Jakobson 1971g [1965]: 350)

The representation of the syntactic system through a diagram becomes a translation process, and the way to trace sign relations (icons) in the connection between parts of the systems, icons that are superimposed onto the network of lexical meanings:

Such linguistic properties as the connectedness of linguistic entities with each other and with the initial and final limit of the sequence, the immediate neighborhood and distance, the centrality and peripherality, the symmetrical relations, and the elliptic removal of single components find their close equivalents in the constitution of graphs. The literal translation of an entire syntactic system into a set of graphs permits us to detach the diagrammatic, iconic forms of relations from the strictly conventional, symbolic features of that system. (Jakobson 1971g [1965]: 351; my emphasis - B. O.)

Within every single word, too, morphemes have a similar iconic structure, so that part of the meaning of a word must be tracked in the iconic combination of morphemes it describes:

Not only the combination of words into syntactic groups but also the combination of morphemes into words exhibits a clear-cut diagrammatic 
character. Both in syntax and in morphology any relation of parts and wholes agrees with Peirce's definition of diagrams and their iconic nature. (Jakobson 1971g [1965]: 352)

Jakobson's great discovery (only in part derived from selection and combination in Saussure) of the two main types of connection between words - syntagm and paradigm - has conspicuous consequences for translation as well. Let us start again from the WesternEuropean background on which Jakobson has built his powerful construction:

It is noteworthy that Saussure's classification had recourse to morphological criteria only, while syntax was actually laid aside. This oversimplified bipolar scheme is substantially amended by Peirce's, Sapir's, and Whorf's insights into wider, syntactic problems. In particular, Benjamin Whorf, with his emphasis on the "algebraic nature of language". (Jakobson 1971g [1965]: 353)

This Saussurean oversimplification is a typical example of the consequences of hyper-specialization that - in every culture where it is promoted - tends to make scholars lose sight of the overall picture. Focusing on a single aspect of language - words, in the given example, as if they could exist in a standalone situation - deprived research of the necessary context. Having in mind the interrelation between oral and written speech, and always considering that oral speech is ontogenetically and phylogenetically the former, is a good way to avoid such a mistake.

In an article of 1956 we can already see the whole exposition of the two principles of verbal language, albeit with a slightly different terminology:

Any linguistic sign involves two modes of arrangement. 1) Combination. Any sign is made up of constituent signs and/or occurs only in combination with other signs. This means that any linguistic unit at one and the same time serves as a context for simpler units and/or finds its own context in a more complex linguistic unit. Hence any actual grouping of linguistic units binds them into a superior unit: combination and contexture are two faces of the same operation. 2) Selection. A selection between alternatives implies the possibility of substituting one for the other, equivalent to the former in one respect and different from it in another. Actually, selection and substitution are two faces of the same operation. (Jakobson 1971c [1956]: 243) 
What is stated here is fundamental for the understanding of speech: the translation of language into speech has these two channels, through which the speaker's mental content must pass. This has obvious and well-known implications on the side of the study of brain functioning. Nevertheless, it has broad implications for the very semiotic theory based on Peirce's main triad formed by sign, interpretant, and object, too.

These two operations provide each linguistic sign with two sets of interpretants, to utilize the effective concept introduced by Charles Sanders Peirce: there are two references which serve to interpret the sign - one to the code, and the other to the context, whether coded or free, and in each of these ways the sign is related to another set of linguistic signs, through an alternation in the former case and through an alignment in the latter. (Jakobson 1971c [1956]: 244)

If we agree with Jakobson that there are two possible types of logical link of a word with another, and we apply this notion to Peirce's schema of the logical development of - both inner and outer speech, the picture we obtain is rather new. If Figure 1 was the former schema, then we obtain something like this new way of representing the lines of translation of meaning (Fig. 2).

$\begin{array}{llll} & & & \\ \text { sign } & \rightarrow \text { interpretants } & \text { object } 1 \\ & \rightarrow & \text { object } 2 \\ & & \text { object } 3 \ldots\end{array}$

Figure 1. Schema of the logical development of speech in Peircean terms.

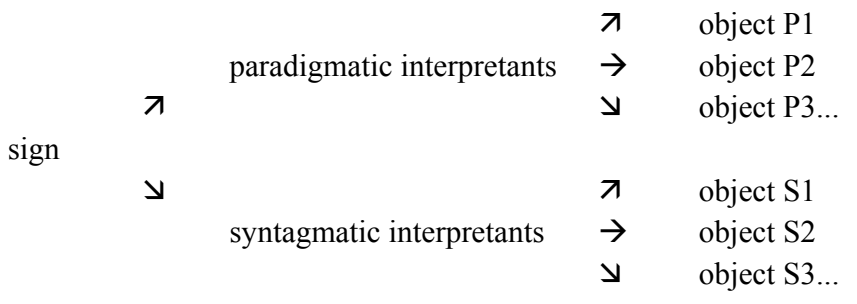

Figure 2. Translation of meaning when applying the two Jakobsonian types of logical links between words to the Peircean schema. 
That pours light on the different outcomes of semiosis, both on the verbal front and on the front of reasoning. If this is the situation from the point of view of inner working, it has consequences on the outer form of speech as well:

The development of a discourse may take place along two different semantic lines: one topic may lead to another either through their similarity or through their contiguity. The metaphoric way would be the most appropriate term for the first case and the metonymic way for the second, since they find their most condensed expression in metaphor and metonymy respectively. (Jakobson 1971c [1956]: 254)

Metaphor is the trope of similarity, since a metaphor is a simile without the explication of the "missing link". And metonymy is the trope of contiguity, since instead of the more immediate word, another one is used that is connected to the first by a logical link of context. From the two different mental principles, also different forms of text are originated:

The principle of similarity underlies poetry; the metrical parallelism of lines, or the phonic equivalence of rhyming words prompts the question of semantic similarity and contrast; there exist, for instance, grammatical and antigrammatical but never agrammatical rhymes. Prose, on the contrary, is forwarded essentially by contiguity. Thus, for poetry, metaphor, and for prose, metonymy is the line of least resistance and, consequently, the study of poetical tropes is directed chiefly toward metaphor. (Jakobson 1971c [1956]: 258-259)

This assertion alone breaks the walls between psychology, linguistics, and textology. And, to all of this, we have to add personal style and idiosyncrasies: the style of a text, consequently, can be analyzed in terms of mental connections:

In manipulating these two kinds of connection (similarity and contiguity) in both their aspects (positional and semantic) - selecting, combining, and ranking them - an individual exhibits his personal style, his verbal predilections and preferences. (Jakobson 1971c [1956]: 255)

Even if syntaxis is a chain, a line, and is therefore bi-dimensional, preventing deviations on a third dimension - as in a hypertext, for example - the normal, horizontal development of a sentence is nonetheless characterized by stylistic devices, above all by word 
markedness: every word can be marked, from a semantic or syntactical point of view:

Any syntactic structure is a member of a transformational chain and any two partially synonymous constructions display an interrelation of markedness and unmarkedness. For example, in English the passive is marked in relation to the unmarked active mood. (Jakobson 1985c [1972]: 90)

In a time when Chomskian "trees" dominate over the whole linguistic universe, Jakobson implicitly argues against them. Speech, more than its "bare intelligence content" (what is described by tree graphs) has many nuances of meaning produced by the choice of different "synonyms", different syntactical forms, different kinds of markedness:

it is still opportune to recall that the code is not confined to what communication engineers call "the bare intelligence content" of speech, but that likewise the stylistic stratification of the lexical symbols and the allegedly "free" variation, both in their constitution and in their combination rules, are "foreseen and provided for" by the code. (Jakobson 1971f [1960]: 573)

This paragraph introduced us to the nexus between inner speech and outer forms of expression. There were many hints at the possibility of development of meaning: this will be the topic of the next paragraph.

\section{Evolution of meaning and invariance}

The mechanism of signification is based on the translation of a sign into an interpretant into an object. Being translation, obviously it is characterized by a partial loss and a partial invariance. And, as all translation processes, it implies also that the result will have new meanings, will add potential meanings to the process. So every passage of information, every logical passage, implies a change of information:

The Metalogicus by John of Salisbury supplied Peirce with his favorite quotation: "Nominantur singularia, sed universalia significantur". How many futile and trivial polemics could have been avoided among students of language if they had mastered Peirce's Speculative Grammar, and particularly its thesis that "a genuine symbol is a symbol that has a general meaning" and 
that this meaning in turn "can only be a symbol", since "omne symbolum de symbolo". A symbol is not only incapable of indicating any particular thing and necessarily "denotes a kind of thing", but "it is itself a kind and not a single thing”. (Jakobson 1971g [1965]: 358)

Jakobson repeatedly refers to Peirce's repeatedly referring to John of Salisbury: every single sign refers to many objects; every one of these objects, in its turn, can be seen as a sign referring to many objects. Signification (and decoding) is a multiple-choice process that, as Jiří Levý (1967) used to say about translation, has a single input and several possible outputs. Every interpretant is a diamond dissecting light into many different rays and colors and directions. The logical line of the speaker's (writer's) mind chooses given signs having in mind a given meaning, but the logical line of the listener's (reader's) mind chooses given meanings having in mind a given interpretation. In this way - through what can be named a continuous "misunderstanding" - , meanings evolve:

This interplay of universals and particulars, which is often underrated by linguists, has for ages been discussed among logicians and philosophers of language. (Jakobson 1985c [1972]: 90)

Specification and generalization thus play a fundamental role in the evolution of meaning, with the peculiarity that their main explicit features do not imply any semantic change at all: specification should only condense, synthesize the general meaning of a sign, and generalization apparently extends, amplifies the meaning to many more objects, but, apparently, without changing it. These two mechanisms, that are key in interlingual verbal translation, too, are continuously at work in normal semiosis:

Peirce's semiotic doctrine is the only sound basis for a strictly linguistic semantics. One can't help but agree with his view of meaning as translatability of a sign into a network of other signs and with his reiterated emphasis on the inherence of a "general meaning" in any "genuine symbol" [CP 2.293], as well as with the sequel of the quoted assertion: A symbol "cannot indicate any particular thing: it denotes a kind of thing. Not only that, but it is itself a kind and not a single thing" [CP 2.301]. (Jakobson 1985b [1956]: 118)

When we use a single word to communicate with the outer world, it is as if we went around with a tray full of mugs, it is as if mugs (possible 
meanings of the single word) came only in sets of many mugs. One mug (special nuance of a word) is the one that interests us in the given chronotopic context, but the other ones are inseparable, and go around with it. When we stop at a table to deliver our tray (word), we put down our tray having in mind one particular mug (acceptation), but our receivers, sitting at the table, since we (inevitably) give them a lot of mugs with different drinks (acceptations), may decide that they prefer to interpret our word as composed of some other drink, and we, senders, don't always realize that. (And, of course the effect is maximized if we go around not with a single word, but with a text composed of many words.) Maybe this also is imputed similarity?

Our word "always bears a greater amount of information than our consciousness is able to extract from it, since at the basis of our words lie our unconscious linguistic sets". (A. E. Sherozia, quoted in Jakobson $1985 \mathrm{~g}$ [1978]: 161)

Metaphor and metonymy, figures of speech in general, and different kinds of imputed similarities are not therefore peculiar to artistic texts, they are simply the fundamental mechanisms of meaning construction, together with generalization and specification.

The metaphor (or metonymy) is an assignment of a signans to a secondary signatum associated by similarity (or contiguity) with the primary signatum. (Jakobson 1971g [1965]: 355)

One mechanism of modification of sense is what Jakobson calls "lexical tropes". A message contains the word "star", and this word has a primary meaning - in the physical sense - and (among others) a secondary meaning (that of a very well known person). Such a duplicity allows potential decoders to opt for one or the other of the two considered meanings, producing the (mis-)understanding that modifies the sense of the text and producing the evolution of meaning.

A partial similarity of two signata may be represented by a partial similarity of signantia, as in the instances discussed above, or by a total identity of signantia, as in the case of lexical tropes [my emphasis - B. O.]. Star means either a celestial body or a person - both of preeminent brightness. A hierarchy of two meanings - one primary, central, proper, context-free; and the other secondary, marginal, figurative, transferred, contextual — is a characteristic feature of such asymmetrical couples. (Jakobson 1971g [1965]: 355) 
This continuous translation process of semiosis is due to the continuous change of context: in every context, a more or less slightly different subcode is used. And every time that a text moves from one context to the next, there is a reciprocal adaptation of the text to the context and of the context to the text. And the text is read (decoded) in a more or less slightly different light:

The convertible code of language with all its fluctuations from subcode to subcode and with all the current progressing changes which this code is undergoing, is to be jointly and comprehensively described by the means of lingusistics and communication theory. An insight into the dynamic synchrony of language, involving the space-time coordinates, must replace the traditional pattern of arbitrarily restricted static descriptions. (Jakobson $1971 \mathrm{f}$ [1960]: 574)

During such a passage from one context to another, it may well happen that specification and generalization work in the direction of translating words into terms and vice versa. This also is a mechanism of meaning-changing:

The ways in which per translationem a nomen turns in discourse into a terminus were intently explored, with many still valid and suggestive linguistic finds, and with a rigid delimination of suppositio formalis (object language) and different varieties of suppositio materialis (metalanguage), neatly discerned by Shyreswoode. (Jakobson 1985e [1975]: 195)

An ingenuous reader could think that, even if we agree with the existence of such a meaning-changing mechanism, there are however words for which that mechanism doesn't occur: proper names. They are very peculiar words that, having been attributed to someone or something in particular, cannot be subject to variance. Our temporary delusion soon faces disillusionment in Jakobson's words:

Even in proper names the "sign design" always has a broader meaning than any single "sign instance". The context indicates whether we speak about Napoleon in his infancy, at Austerlitz, in Moscow, in captivity, on his deathbed, or in posthumous legends. (Jakobson 1971e [1959]: 268)

Communication and evolution of meaning through translation are at work in any kind of intrapersonal (thought) and interpersonal relation. Therefore, the point in this case - as in the case of interlingual verbal translation - is to find the means to define the invariant: what 
remains of the original intended message in the final effective message.

[...] replying to the question of invariance: [...] "the word and its meaning are both general rules" [CP 2.292]. (Jakobson 1985f [1975]: 252)

Interlingual verbal translation and general semiosis have a very similar course, and they can be used for a reciprocal checking of the other's functioning. Here we see how in Jakobson's (and Shannon's) opinion the invariant can be defined:

The semiotic definition of a symbol's meaning as its translation into other symbols finds an effectual application in the linguistic testing of intra- and interlingual translation, and this approach to semantic information concurs with Shannon's proposal to define information as "that which is invariant under all reversible encoding or translating operations", briefly, as "the equivalence class of all such translations". (Jakobson 1971f [1960]: 578)

Jakobson himself sees the affinity between tropes (metaphor and metonymy) and usual meaning production in "normal" (non-artistic) texts. The shared part between Jakobson and Shannon is the existence of a part of meaning that is expressed, and another part that is not expressed, and may be - arguably — guessed in different ways by different decoders:

Each and every sign is a referral (renvoi) (following the famous aliquid stat pro aliquo). The parallelism alluded to by the master and theoretician of poetry, Gerard Manley Hopkins, is a referral from one sign to a similar one in its totality or at least in one of its two facets (the signans or the signatum). One of the two "correspective" signs, as Saussure designates them, refers back to another, present or implied in the same context, as we can see in the case of a metaphor where only the "vehicle" is in praesentia. (Jakobson 1985d [1975]: 215)

In this process of decoding, the presence/absence of elements means that what is absent in the text must be present in the context. Such problem of presence involves the referral to different times. Peirce attributes to the three types of signs the three different times (symbolfuture, index-present, icon-past). Jakobson holds that the artifice [priem], as a fourth dimension of signification, is a bridge over times: 
"Parallelism" as a characteristic feature of all artifice is the referral of a semiotic fact to an equivalent fact inside the same context [...]. This [...] allows us to complement the system of times which Peirce includes in his semiotic triad [...]. The artifice retains the atemporal interconnection of the two parallels within their common context. (Jakobson 1985d [1975]: 216)

Translation is, therefore, transportation of a text from one context into another. And, on the other side, communication is the ability to decide what is necessary to express and what can be taken/given for granted since it is suggested by the context, with all the consequent problems of redundancy and loss. This is the subject of the next paragraph.

\section{Cultural basis of translation}

What is lacking in the thought of some very well-known linguists, before Halliday at least, - like, for example, Saussure and Chomsky - is the effort to take into account a fundamental component of speech, or, the main difference between speech and language: context. That may have been the consequence of a too narrow, specialized approach to the subject. In other words, it is the consequence of linguistics meant as a science that can exist without considering all the semiotic and psychological aspects implied in verbal language:

Peirce denies (in the same way as the Gestalt psychologists) the possibility of speaking about constituents without analyzing the structural relation between the constituents and the whole. (Jakobson 1985f [1977]: 252)

A correct (complete) setup of the problem implies the contextual, cultural dimension, as any translator can testify. As we have seen in the previous paragraph, not only classical - interlingual, verbal translation, but also every act of signification, every intra- and interpersonal communication is transportation of a text from a context into another. But, since the text is not a thing, but it is a living being that has a mutual relationship with the environment in which it lives, changing its environment means changing its reaction to it, like a sheep passing from a cold winter to a hot summer, with the consequent change of contextual covering.

For this reason, considering the context is fundamental even when speaking of the most elementary principles of communication and 
translation, i.e. semiosis. Even Peirce - quoted by Jakobson speaks of a selective interpretant, whose difference from the "usual" interpretant is that the context ("reality") contributes to its significance:

Signs are viewed by Peirce as equivalent "when either might have been an interpretant of the other" [CP 5.569]. It must be emphasized again and again that the basic, immediate, "selective" interpretant of any sign is "all that is explicit in the sign itself apart from its context and circumstance of utterance" [CP 5.473], or in more unified terms: apart from its context either verbal or only verbalizable but not actually verbalized. (Jakobson 1985b [1956]: 118)

\section{Peirce writes:}

We have to distinguish the Immediate Object, which is the Object as the Sign itself represents it, and whose Being is thus dependent upon the Representation of it in the Sign, from the Dynamical Object, which is the Reality which by some means contrives to determine the Sign to its Representation. [CP 4.536]

It is clear that in natural language, in speech, we have to consider above all the dynamical object, since the immediate object is mostly an abstraction.

The explicit (written, spoken) text is but a minimum percentage of the message that must be completed by contextual information. Since the context does not 'suggest' which parts of it should be considered in single occurrences of text, there are the well known to translators problems of misunderstanding due to the different contextualization of the utterance:

The probabilistic aspect of speech finds conspicuous expression in the approach of the listener to homonyms, whereas for the speaker homonymy does not exist. When saying $/ \mathrm{s} \Lambda \mathrm{n} /$, he knows beforehand whether "sun" or "son" is meant, while the listener depends on the conditional probabilities of the context. For the receiver, the message presents many ambiguities which were unequivocal for the sender. The ambiguities of pun and poetry utilize this input property for the output. (Jakobson 1971f [1960]: 575-576)

Creativity is, thus, basic for communication, for understanding, for translating. Such creativity is partly conscious and partly unconscious. A good translator (communicator) — and a good semiotician — uses 
a generous dose of creativity in inferring, conjecturing possible interpretive keys:

"any linguistic compromise occurring between peoples speaking different languages" inevitably involves "a certain portion of conscious creativity" [...] unconscious (nieświadome) psychical processes also have the capability of becoming conscious (uświadomianie), but their potential consciousness is actually identifiable with the unconscious (nieświadomość). (Jakobson 1985g [1978]: 152; Jakobson's quotations are from Baudouin de Courtenay)

Between unconscious and conscious use of language there is a relationship similar to the one existing between language and metalanguage, translation (semiosis) and reflections on translation (semiosis). Everybody can translate (code/decode) aconsciously, without realizing why, for whom, to what aim, without being able to explain why s/he has made given choices. From this wild state, 'translators' can grow to a conscious state from which they can observe the 'wild life' of their being translators in a natural state and detach from it to observe it as an object, something 'other':

the influence of the consciousness [on language] can and does impede the development of a language; it counteracts the influence of unconscious forces - forces which by and large promote a more rapid development of language - and does so precisely for the purpose of making language a common instrument for the unification and mutual comprehension of all contemporary members of a nation, and its forebears and descendants, as well. (Jakobson 1985g [1978]: 151)

Every consideration about speech (language in context) must necessarily account for the environmental variables. Since invariance is a key notion in semiotics/translation, to speak about it one must consider the three directions in which, according to Jakobson, a speech can be contextually different: explicitness/implicitness, historicization/ modernization, and formality/informality.

Any verbal code is convertible and necessarily comprises a set of distinct subcodes or, in other words, functional varieties of language. Any speech community has at its disposal 1) more explicit and more elliptic patterns, with an orderly scale of transitions from a maximal explicitness to an extreme ellipsis, 2) a purposive alternation of more archaic and newfangled dictions, 3) a patent difference between rules of ceremonial, formal and informal, slovenly speech. (Jakobson 1971h [1967]: 667) 
It does not make any sense to study speech in isolation, to study language as an abstract discipline that has nothing to do with everyday reality. That is not communication, it is an abstraction that can be used to exercise the mind as a game.

First, every single constituent of any linguistic system is built on an opposition of two logical contradictories: the presence of an attribute ("markedness") in contraposition to its absence ("unmarkedness"). [...] And second, the continual, all-embracing, purposeful interplay of invariants and variations proves to be an essential, innermost property of language at each of its levels. (Jakobson 1985c [1972]: 91)

The point in speech is not the structure of an utterance, the primitive meanings of the signs implied, the Chomskian 'deep structure' of a sentence. Such proceedings do not help research on translation in any way, as no summary of a work of art can be a substitute for its prototext. What the professional translator (and the semiotician) strives to understand, and mostly cares for, is the form of expression of a given content:

These two dyads - markedness/unmarkedness and variation/invariance are indissolubly tied to the be-all and end-all of language, to the fact, as Edward Sapir [...] put it, that "language is the communicative process par excellence in every known society”. (Jakobson 1985c [1972]: 91)

The key word for a translator is "variation": of the thousand of thousands ways to say something, in how many ways it is possible to describe the single variation chosen by the given author in the given passage. And, by shifting the context, in what way can we try to preserve some kind of invariance in the passage?

It is the context-sensitivity of a natural language at all levels that provides it with a unique abundance of free variations. The dialectical tension between invariants and variables, which in their own way also appear to be pertinent, ensures the creativity of language. (Jakobson 1985c [1972]: 89)

In the first years of Soviet power, someone felt the need to change names of things so that they could reflect their 'objective' state. Jakobson cites the case of the 'rise' and the 'setting' of the sun, and the people who had proposed a revision of the vocabulary. The change of context in question, in this case, is not the physical context, but human knowledge of the physical context. Jakobson explains the superfluity of 
such a linguistic change by quoting (implicitly) Peirce and his view of interpretation as translation, of interpretant as translatant:

In the first years of the Russian revolution there were fanatic visionaries who argued in Soviet periodicals for a radical revision of traditional language and particularly for the weeding out of such misleading expressions as "sunrise" or "sunset". Yet we still use this Ptolemaic imagery without implying a rejection of Copernican doctrine, and we can easily transform our customary talk about the rising and setting sun into a picture of the earth's rotation simply because any sign is translatable into a sign in which it appears to us more fully developed [CP 5.594] and precise. (Jakobson 1971d [1959]: 262)

In other words, we are able to speak about the 'rise' and the 'setting' of the sun without being forced to the dogma of words since we are able to translate them. If cultural context influences the way one speaks, on the other hand the linguistic code influences the way one must express oneself. Explicitness and implicitness are not only part of the cultural context at large; they are part of the linguistic code as well.

Languages differ essentially in what they must convey and not in what they can convey. [...] Naturally the attention of native speakers and listeners will be constantly focused on such items as are compulsory in their verbal code. (Jakobson 1971d [1959]: 264-265)

In any natural language we can express absolutely everything, since there are infinite combinations of signs. (Or, to be more exact, the number of possible combinations is given by the number of words raised to the same number power: a quantity so high that, for any human - mortal! - being, to all practical purposes, results higher than the combinations one has time to try in a lifespan.) If this is still considered not enough, Jakobson suggests thinking of the opportunity to create words.

All cognitive experience and its classification is conveyable in any existing language. Whenever there is a deficiency, terminology can be qualified and amplified by loanwords or loan-translations, by neologisms or semantic shifts, and, finally, by circumlocutions. (Jakobson 1971d [1959]: 263)

For this reason, the different structure of languages is not an insurmountable obstacle in interlingual translation, it implies the rendering of senses that in one language are expressed by grammatical categories though paraphrases or other lexical means: 
If some grammatical category is absent in a given language, its meaning may be translated into this language by lexical means. Dual forms like Old Russian brata are translated with the help of the numeral: 'two brothers'. It is more difficult to remain faithful to the original when we translate into a language provided with a certain grammatical category from a language lacking such a category. [...] In order to translate accurately the English sentence I hired a worker, a Russian needs supplementary information. (Jakobson 1971d [1959]: 263-264)

If from a narrowly linguistic - lexicalistic - point of view such a problem can be a real problem, from a semiotic point of view it is trivial: what in a language is expressed by lexical means, in another language is expressed by grammatical means, in a sort of intersemiotic translation. Semiotics adds one more scientific dimension to the study of verbal communication. And, as Jakobson shows, in such a semiotic approach the notion of "translation" is absolutely central. It is not linguistics that studies translation, as some scholars of the old lexicalist school have been thinking for more than half a century; it is translation that studies semiotics, including linguistics. Maybe translation is an imputed similarity as well? ${ }^{2}$

\section{References}

CP $=$ Peirce, Charles Sanders 1931-1935, 1958. The Collected Papers of Charles Sanders Peirce. Vols. 1-6 [Hartshorne, Charles; Weiss, Paul (eds.), 19311935]; vols. 7-8 [Burks, Arthur W. (ed.), 1958]. Cambridge: Harvard University Press.

Jakobson, Roman 1971a. Selected Writings, vol. 2, Word and Language. Den Haag: Mouton.

— 1971b. Retrospect. In: Jakobson 1971a: 709-722.

- 1971c [1956]. Two aspects of language and two types of aphasic disturbance. In: Jakobson 1971a: 239-259. [Original ed. 1956, Fundamentals of Language, Den Haag: Mouton.]

- 1971d [1959]. On linguistic aspects of translation. In: Jakobson 1971a: 260266. [Original ed. in: Brower, R. A. (ed.) 1959. On Translation. Cambridge: Harvard University Press.]

- 1971e [1959]. Linguistic glosses to Goldstein's "Wortbegriff”. In: Jakobson 1971a: 267-271. [Original ed. 1959, Journal of Individual Psychology 15.]

2 Acknowledgement. The work on the present article has been financed by the ETF (Estonian Science Foundation) Grant no. 5717. 
— 1971f [1960]. Linguistics and communication theory. In: Jakobson 1971a: 570-579. [Original ed. 1960, Proceedings of Symposia in Applied Mathematics 12, New York.]

— 1971g [1965]. Quest for the essence of language. In: Jakobson 1971a: 345359. [Original ed. 1965, Diogenes 51: 21-37.]

- 1971h [1967]. Linguistics in relation to other sciences. In: Jakobson 1971a: 655-696. [Original ed. 1967, Linguistics. In: Main trends in Social Research, Unesco.]

- 1971i [1968]. Language in relation to other communication systems. In: Jakobson 1971a: 697-708. [Original ed. 1968, Languages in Society and in Technique, Milano: Olivetti.]

- 1985a. Selected Writings, vol. 7, Contributions to Comparative Mythology. Studies in Linguistics and Philology, 1972-1982. Berlin, New York, Amsterdam: Mouton.

- 1985b [1956]. Metalanguage as a linguistic problem. In: Jakobson 1985a: 113-121. [Original ed. 1956, Annual Meeting of the Linguistic Society of America.]

- 1985c [1972]. Verbal communication. In: Jakobson 1985a: 81-92. [Original ed. 1972, Scientific American 227(3, September).]

- 1985d [1975]. A glance at the development of semiotics. In: Jakobson 1985a: 199-218. [Original ed. 1975, Coup d'œil sur le développement de la sémiotique, Bloomington: Indiana University Press.]

- 1985e [1975]. Glosses on the medieval insight into the science of language. In: Jakobson 1985a: 185-198. [Original ed. 1975, Mélanges linguistiques offerts à Émile Benveniste, Paris.]

- 1985f [1977]. A few remarks on Peirce, pathfinder in the science of language. In: Jakobson 1985a: 248-253. [Original ed. 1977, Modern Language Notes 92, 1026-1032.]

- 1985g [1978]. On the linguistic approach to the problem of consciousness and the unconscious. In: Jakobson 1985a: 148-162. [Original edition Prangishvili, A. S.; Sheroziya, A. E.; Bassin, F. V. (eds.) 1978, Bessoznatel'noe: priroda, funktsii, metody, issledovaniya, Tbilisi.]

Levý, Jiří 1967. Translation as a decision process. In: To Honor Roman Jakobson. Essays on the occasion of his seventieth birthday. Den Haag: Mouton, vol. 2: 1171-1182.

\section{Якобсон: перевод как предполагаемое сходство}

Якобсон пытался в своих эссе вместить пирсовскую типологию знаков (икона, индекс, символ) в рамки собственной бинарной логики, в которой каждый признак текста может быть рассмотрен как 0 или 1 (наличие, присутствие). В ходе этого он пользовался парами признаков «сходство vs смежность» и «предполагемое vs существующее» и пришел к выводу, что пирсовская триада не покры- 
вает понятия «предполагаемого сходства». Отсюда и его поиски отсутствующего понятия. Данная статья основывается в основном на работах Якобсона и пытается показать, что именно понятие перевода является этим отсутствующим звеном.

Исходя из основной триады Пирса и ее первоначальной интерпретации западными учеными соссюрианского толка, интерпретанта здесь рассматривается в качестве субъективного и аффективного компонента знака и его интерпретации. Синтаксис, рассмотренный в терминах Пирса и Якобсона, является иконическим. Развитие значения, являющегося основой любой коммуникации, возможно благодаря конструкциям и метафорическим и метонимическим связям. Последняя часть статьи рассматривает культурные импликации коммуникации и перевода.

\section{Jakobson: tõlge kui oletatav sarnasus}

Jakobson on oma esseedes üritanud Peirce'i märgitüpoloogiat (ikoon, indeks, sümbol) mahutada enda binaarsesse loogikasse, kus igat tekstitunnust võib iseloomustada vastavalt kas 0 või 1-ga (puudub, olemas). Selle käigus on ta kasutanud tunnustepaare "sarnasus versus külgnevus" ja "oletatav versus faktiline" ning on jõudnud järeldusele, et Peirce'i triaad ei kata "oletatava sarnasuse" mõistet. Siit lähtuvad ka tema otsingud antud mõiste leidmiseks. Käesolev essee, mille ideeline alus ja viitestik pärineb suuremalt jaolt Jakobsoni esseedest, üritab näidata, et just tõlke mõiste on siinkohal puuduvaks lüliks. Lähtudes Peirce'i põhitriaadist ning sellest, kuidas Saussure'i-mõjulised Lääne teadlased seda algselt tõlgendasid, käsitletakse tõlgendit (interpretanti) siin märgi ja selle tõlgenduse subjektiivse ning afektiivse komponendina. Süntaks on Peirce'i ja Jakobsoni mõistetes ikooniline. Kommunikatsiooni kui sellise põhijooneks olev tähenduse areng on võimalik tänu konstruktsioonidele ning metafoorsetele ja metonüümsetele seostele. Artikli viimane osa käsitleb kommunikatsiooni (ja tõlke) kultuurilisi implikatsioone. 